\title{
Early History of Computing in Denmark
}

\author{
Søren Duus Østergaard \\ Duus.Communications ApS \\ soren@duus.com
}

\begin{abstract}
This paper describes how the predecessors to modern computers, the family of equipment we describe as The Punch Card Machines, entered the Danish and Nordic Markets. It also describes how it paved the way for the relatively rapid take-off in the Nordic market of the 'real' computers. The paper also sheds light on the competitive situation, the key applications, and the heavy influence of public regulations on market development. Written in conjunction with the studies on the roots of IBM Denmark, founded as a limited company as late as 1950 , the paper makes use of archives and material hitherto not published.
\end{abstract}

Keywords: Bull, CTM, Hollerith, IBM, Max Bodenhoff, Powers, punched cards, Remington.

\section{Introduction}

Although the focus of the HINC3-conference is the development and take-up of IT in the Nordic countries, this did not just happen "out of the blue," but was the logical consequence of hard work and scientific breakthrough abroad and within the Nordic regions. It was also definitely useful because the market situation was well prepared for this type of practical application created to increase the human capacity for calculating, storing, and analyzing vast amounts of data.

Even more interesting to social and organizational researchers is the way punchedcard based companies and customers were organized, how the competitive landscape, patterns of competition, the constant pressure on innovation, and the need for skilled employees actually mirrors what we have witnessed from 1960 onwards. It was during that time when 'real computing' was a matter of making companies more efficient and competitive as well as increasing the speed, accuracy, and accountability of the public sector.

As this paper is based on research into the roots and origins of IBM Denmark, the focus is on the Danish market. However, it is evident that much Nordic cooperation was actually unfolding before and even during World War II.

\section{The First Automatic Calculation Machines in Denmark}

As early as 1911, the Danish Central Bureau of Statistics ordered the first set of socalled Hollerith machines from the German agent, Mr. W. Williams, in Berlin to 
assist in finalizing the census of 1910 [1]. The Hollerith equipment, first used in connection with the U.S. Census in 1890, was based on patents owned by Herman Hollerith who developed the equipment specifically with large statistical applications in mind. These machines were rented (as all Hollerith equipment and indeed for many years IBM computers and equipment also) and no service specialists accompanied the machines that comprised two vertical sorters, one tabulator, six hand punches, and one hand gang punch. These machines - except the hand punches - were returned in 1912 and, according to employees, they were difficult to use and had been out of order for most of the time.

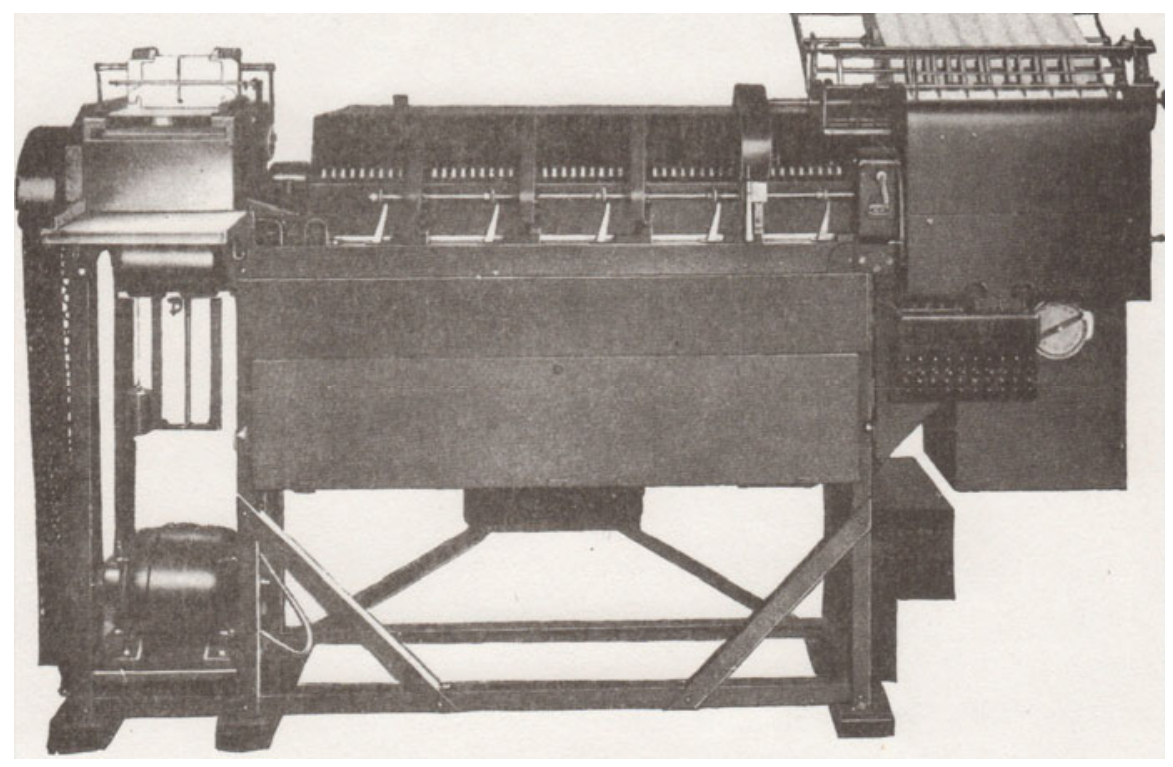

Fig. 1. A Hollerith Tabulator unit with an automatic writing unit [1]

In 1915, the Danish insurance company Hafnia entered into an agreement with the Hollerith agent in Berlin to deliver equipment and punched cards, in order to celebrate Hafnia's fifty-year anniversary in 1922. The machines were delivered in 1920 - a vertical sorter (15,000 cards/hour), and a small tabulator which was replaced after a period by a tabulator that arrived directly from the U.S.. The technician that received this parcel was astonished that he was able to put it together and have it operational in a short time. His name was Henrik Hartzner, later to become CEO of Machines Bull in Denmark [1].

\section{The Danish Hollerith Agency}

Max Bodenhoff, a dynamic young Danish businessman, was an agent for the Royal Typewriter Company when he received a letter in 1920 from a former Royal salesman, Mr. Jennings, who now represented IBM in Europe. In Max B's own words: 
In 1920 I got a letter from Paris inviting me to participate in an international training course in Berlin so I could learn about the so-called Hollerith System.

... This was the first international course created as a pilot and run by $\mathrm{Mr}$. Jennings and an extremely nice teacher, Mr. Hide, from the U.S. These two persons were supposed to train us in this extremely odd system [2].

The course consisted of one week of technical training that obviously mostly went over Max Bodenhoff's head, and a one-week sales course that he took to his heart.

The "canvassing technique," as Max Bodenhoff learned, brought him some success relatively soon. He first targeted the Central Bureau of Statistics - and was almost thrown out, as they recalled their experiences from 1911-12. He was asked not to return, but Max Bodenhoff went instead to the manager of the Bureau, Mr. Cohn, and complained that he, who represented one of the world's largest companies, was being treated as a mere seller of shoe strings; he asked for information and numbers so he could make a detailed and realistic offer. Surprisingly, Mr. Einar Cohn agreed and gave him the requested information. Armed with this, he went to Hafnia, the only other company with experience in Hollerith equipment, and asked Mr. Hartzner to help him calculate that the Bureau of Statistics could have saved 36,000 DKK had they used Hollerith equipment for the 1920 census. This helped, and after a month he had his first order.

Max Bodenhoff's second customer became the Danish National Railways. He focused the attack on its statistics department, but the manager did not want any changes; fortunately, a younger manager, Mr. Herschend, replaced him. In Max Bodenhoff's own words:

I arrived packed with papers and descriptions, and told Mr. Herschend that he was probably very able to extract the lesson from these papers. I also informed him that Swedish Railways had recently sent a committee of three specialists to New York to study the system [2].

Mr. Herschend did indeed take the opportunity and used the Hollerith system to keep track of goods and railway wagons in a way never done before. In Max Bodenhoff's own words:

This department - until now just looked upon as dull and unimportant - was suddenly able to produce information and data at a detail and speed that no Ministry for Public Works had been able to obtain before [2].

Herschend thus became a star in the Railways - and Max Bodenhoff could point to an important reference. Success materialized when he negotiated a contract for Hollerith equipment with the Danish Employers' organization in 1924.

\section{Competition in the Early Days}

\subsection{Hollerith and Powers}

Max Bodenhoff and Hollerith were not the only players in the field of punched cards. A creative engineer, James Powers, had already developed an improved keypunch in 
the U.S. in 1910 and incorporated his own company in 1911, just when some of Hollerith's original patents were running out. In addition, the U.S. Census for 1910 was now deploying Powers' equipment [1].

The previous occurrences were some of the reasons Herman Hollerith sold his company to the Computing-Tabulating-Recording Company that later developed into IBM. In addition, the rental business approach required large investments that Hollerith and his investors were not ready to fund. Apart from some technical improvements of the original Hollerith equipment, Powers also had another business strategy, where customers were also able to buy his equipment, while CTR ruthlessly maintained Hollerith's original lease/rental strategy. The other major difference between the two original systems was that while Hollerith was a sworn fanatic of electro-mechanical solutions, Powers invented a low-cost yet still effective mechanical solution.

There is no doubt, however, that the presence of two vendors gave rise to fierce competition that required constant innovation and improvements in both companies, and soon Powers, as Hollerith, looked to Europe as a potential growth market. The first orders for Powers' equipment in Europe seemed to have come from the Swedish Bureau of Statistics as early as 1913, but soon Powers entered some of the major markets where Hollerith Equipment had until then been the only vendor. In the UK, the Powers Company fiercely competed with British Tabulating Machines, an independent vendor selling Hollerith equipment, and on the continent, the main battle was between Powers Germany and DeHoMag - Deutsche Hollerith Machinen AG [1]. All of these local companies invented new devices and improvements and took out patents to protect themselves. This later became the artillery for intense legal battles that would be fought during the 1930s - a trend we also saw in the 1970s (Peripherals, mainframes) and in the 1980s (PCs) - as well as in SW Patent disputes since the 1990s.

\subsection{Frederik Rosing Bull Enters the Danish Market}

In Norway, Frederik Rosing Bull was a consultant for the Storebrand Insurance Company, who in 1918 began to construct an improved accounting machine - or as he called it - an automatic registration machine for statistical or similar purposes [1]. The patent was issued in 1919, the first machine was sold to Storebrand, of course, but the second was sold to Hafnia in Denmark. Henrik Hartzner tells us:

As his managing director in a Nordic insurance magazine had read about 'Storebrand's new machine, I was sent to look at it, and as result we bought one 'registration machine' that was installed on September 30 1922. It was a combined sorting and accounting machine with $3 \times$ 9-digits counters [2].

After some correspondence with Frederik Bull, additional orders were placed and Hafnia returned all Hollerith equipment on July 18 of 1923, at which time the new Bull accounting machines arrived. They were produced at Kr. Ormestad's machine shop and arrived together with Frederik R. Bull, who supervised the installation. Hafnia kept these machines until 1930, when they were replaced by newer Bull equipment. 
Henrik Hartzner became general agent for Bull in Denmark in 1925, and already the same year sold a Bull machine to the Central Bureau of Statistics and later the same year to the Tryg Insurance Company. Hafnia updated the Bull equipment during the 1930s and became the reference customer in Denmark. This early success explains part of the relative strength of Danish Machines Bull in the 1950s and 1960s [3].

However, Frederik Bull died young, already in 1925, and willed his patents to the Norwegian Cancer Foundation, from where they were eventually bought to become the foundation of the Compagnie Machines Bull.

\section{Service Bureau Business - Challenges and Disappointments}

\subsection{Early Attempts to Create an IBM/Hollerith Service Business}

Already in 1921, Max Bodenhoff recognized the need to create a Service Bureau business, as he was approached by (RFI) Revisions- og Forvaltningsinstitutet (Later Deloitte DK), an institution with 150+ traveling auditors who controlled banking companies [4]. However, RFI demanded an exclusive contract with the Service Bureau business for ten years, and since the general manager of IBM in Europe, Mr. Jennings, would only agree to five years and a cap of fifty thousand punched cards to be used annually, this effectively ended the negotiations and RFI went to Powers for help.

However, Max Bodenhoff did not give in so easily. In 1930, he managed to get together a large group of medium-small insurance companies for the purpose of creating a fully developed service bureau, even hiring the best person from the Central Bureau of Statistics as the operating manager. Nevertheless, when the general manager of IBM Europe arrived, now a Mr. Jones, Max Bodenhoff was disappointed again:

However, it was against the policy of the company that the agents ran a service bureau and I had to give up the plans and pay the man I had hired six months' salary for doing nothing!

Moreover, to make matters worse, all the insurance companies went to Powers. Still, he kept focus on what we today would have called the SMB-segment, recognizing that a service bureau sales channel was the only way to create a long lasting customer relationship with smaller clients and to keep them growing until they were convinced of the value of renting equipment themselves [2].

One might wonder why Max Bodenhoff did not dissolve the relationship with IBM. He said himself that he maintained the relationship because he was simply so impressed by the IBM global management, in particular the general manager, Thomas Watson, who returned the friendship and in many presentations referred to Max Bodenhoff as one of the most well run IBM agencies. Max Bodenhoff and his wife not only enjoyed the friendship of Thomas Watson, but also of his wife and four children, who used to travel with "Daddy" when he was abroad inspecting business partners in Europe. From Max Bodenhoff's notes, we also learn that Thomas Watson also personally worked to maintain the relationship between the agents and the Nordic general managers of the IBM companies, which showed their value during World 
War II and beyond. The charisma of T. Watson was legendary, and he was a sort of icon for multinational companies during his lifetime.

\subsection{Depression and Foreign Exchange Control}

In 1931, the Danish Government created the Exchange Center (Valutacentralen), in order to meet the worldwide crisis and its impact on Danish foreign exchange reserves. Consequently, in order to spend foreign exchange, importers had to seek permission. Since the policy of this organization was extremely tough, in practice, only government import allowances for punched card equipment were granted including permission to import equipment for the exchange center itself. This was an important order as the need for calculations rose dramatically during the 1930s. The only other important order in 1932 was a contract with Unilever Denmark, delivered in 1933 [5].

Max Bodenhoff's reason for pushing for a service bureau approach did not diminish as the 1930 crisis advanced; in addition to this, Denmark was primarily an agricultural nation that at the time only had ten companies and institutions with more than one thousand employees.

Finally, IBM company policy changed and Mr. Jones, the new general manager of IBM Europe, informed Max Bodenhoff that he would receive the green light to create a service bureau. This proved not to be at all too early and the creation of the service bureau actually helped the business of Hollerith Equipment to survive during the Second World War. However, the take-up was slow, as almost all insurance companies were now using Powers (now UK-based Powers-Samas). The turnover for the service business in 1932 was $\$ 645$, rising to $\$ 2,527$ in 1933 , causing stagnation again [2].

The portfolio of customers grew with AU (the Employer Organization's insurance company) in 1934 and another minor insurance company two years later. In 1938, Max Bodenhoff decided to increase the sales force. He employed eight people, and had a turnover of $\$ 6,000$ at the service bureau plus $\$ 5,000$ per month from rental equipment.

\section{A Short Overview of the Competitive Situation in the 1930s}

Much happened technically during the late 1920s to strengthen the competitiveness of the machinery developed by the two, soon to become three, major players in the punch card arena. The battle for applications was mirrored in the explosion of new devices able to print, carry over intermediary results, cross-tabulate, perform simpler accounting applications and, not least, increase the speed capacity. An 80-column card replaced the original 45-column punched card that Hollerith introduced in a very clever way that meant existing machinery only needed small changes to adapt to the new standard. This was the first major "systems migration."

Nevertheless, considering the market and the machinery, there was little doubt that the Powers-Samas products were better than the Hollerith equipment, which was, however, more than offset by the IBM's sales force - they simply had more customers. 
Powers-Samas in the UK became Remington Rand in the U.S. and Europe, as the Rand Corporation acquired the Powers' patents. There had been minor disputes between IBM and Powers Germany up to then, but with Remington-Rand's greater muscle, a serious struggle over patents developed between DeHoMag and Remington $[6,7]$.

In addition, the battle for Frederik Bull's patents also started in the early 1930s [1]. An exhibition in Paris in 1930 displayed Bull machines produced by the Swiss Egli Company that had acquired the Bull patents from Norway. The Egli Company was not ready for production and it was looking for partners. Both IBM and Remington Rand flirted with the idea of taking over Cie des Machines Bull, as the incorporated French production company and Egli affiliate was called. The vice president of Bull actually invited IBM management to inspect the quality of the equipment in 1932, and the proposal was presented to Tom Watson. He hesitated, and eventually turned down the proposal, in spite of the technical evaluation that the machines definitely had growth potential. It was obvious that the threat of the inspection of IBM's monopolistic behavior that the U.S. Ministry of Justice had announced it would start kept Tom Watson away from a direct confrontation.

However, although French IBM had bought 85 percent of the shares in Egli, the Swiss Bull Company, all production and growth took place in the French Bull Compagnie. Due to this, IBM and Cie des Machines Bull also continued the legal battle over who owned which patents until the war broke out $[1,8]$

This is therefore the brief account of why an excellent Norwegian invention ended up in France, why the antitrust legislation of the U.S. (as much later in EU/Europe), just by its presence, would influence business decisions, in order to strengthen competition - and why international companies and their behavior had considerable impact on the Nordic customers' daily operations.

\section{War - Emergency Operations and Innovative Actions}

When the German Wehrmacht occupied Denmark and attacked Norway on April 9 1940, Max Bodenhoff received a visit from two high-ranking German officers that wanted to inspect the service bureau. However, since the U.S., at that point in time, was not yet in the war, they left without further notice. Even after the attack on Pearl Harbor, they did not interfere with the Hollerith Service Bureau and it was the general opinion that its work was of importance for the Danish administration and production upon which the Germans were depending. This may be easier to understand after seeing the proposal prepared by Max Bodenhoff for the National Bank of Denmark on how to administer the so-called Clearing Account, which the German Wehrmacht used to have Denmark finance all the costs of keeping the Wehrmacht operational in Denmark [2].

During the first few years, business was very slow, but after the German defeat at Stalingrad in the winter of 1941-42 trading and industrial companies became interested in starting accounting at the Service Bureau, and soon it was necessary to have a two-shift operation.

Getting punched cards had already become a major problem in 1941; but, thanks to his connections with Swedish IBM, Max Bodenhoff managed to get hold of a 
worn-out printing machine from the Swedish postal service and negotiated an agreement with Munksjö paper mill for the export of cardboard material, so that card manufacturing could begin in Denmark from early 1942. All import of equipment was cancelled, and the Service Bureau plus the skilled customer engineers kept the machinery going for the duration of the war. Similar arrangements were made between IBM Sweden and IBM Finland [2].

On January 27 1943, the Royal Air Force attacked Burmeister \& Wain, the large Danish industrial company located at Christianshavn. This raid was supposed to demonstrate what the Allied forces would do unless the Danish Resistance started its sabotage. Included in the collateral damage were the deaths of several civilians and the destruction of dwelling houses. As Max Bodenhoff's office was, at the time, located in the center of Copenhagen, he felt obliged to move to the suburbs and finally to the House of Danish Industry at a considerable increase in rent.

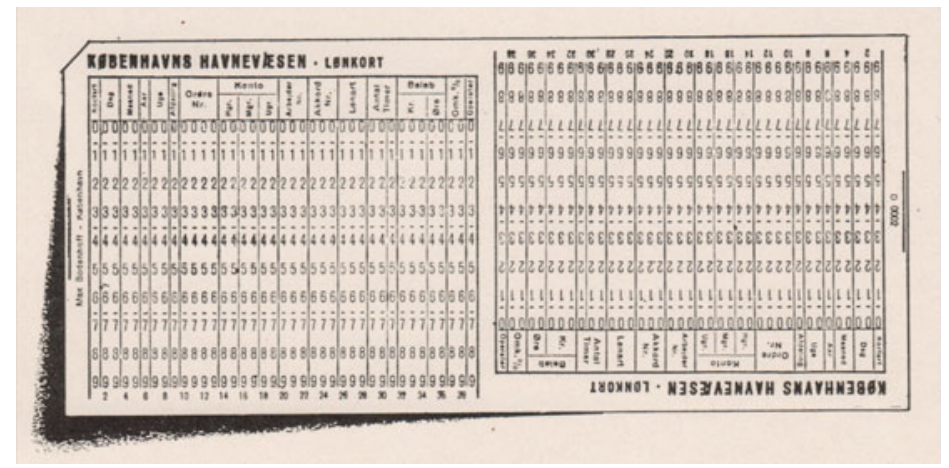

Fig. 2. An 80-column Punched Card used for calculation of salaries and wages, Copenhagen Harbor 1943-46

Nevertheless, when peace finally came on the eve of May 4, 1945, Max Bodenhoff could tally up, with satisfaction, an intact business operation, twenty-five employees, a rental base that was still around $\$ 5,500$ per month, but a turnover at the Service Bureau amounting to $\$ 28,000$ per year. The situation indicated that new customers had been acquired and the outlook on this evening was as bright as ever. In addition to this, his staff had used the war years to develop a variety of applications and demonstrations for different industries ranging from shipyards to retail to manufacturing and government, based on the strategy that applications were, after all, more important than machinery. In a way, this attitude preceded the much later change in IBM from a hardware company to a services company during the 1990s [2].

\section{The Postwar Years}

The plans were already drawn - Max Bodenhoff never lacked initiative [4]. His ambition was to establish affiliates and service bureaus in the three large provincial cities - but optimism soon disappeared as it became clear that the import restrictions were not going to eased in the near future; no new machinery was allowed entry into 
Denmark until 1948. In addition, the many sales pitches, presentations, as well as application descriptions that had been developed and offered to customers and prospects during and immediately after the war could even turn against the Hollerith department. This was because the National Bank of Denmark categorically denied the use of U.S. dollars to buy new equipment, and it would grant only a very restricted quota on extensions of installed equipment. Similar restrictions were not imposed on Powers-Samas (UK based) or on Cie Machines Bull (French), as the European currencies were not being managed as restrictively. Thus, all the effort of creating interest and understanding might have resulted in victories for the competition.

Furthermore, the installed rental based equipment was worn out as was the machinery in the Service Bureau. Fortunately, in 1946, the authorities gave permission to import a complete set of IBM machinery that the U.S. Army used during the campaign in Northern Germany, 1944-45. Permission had also been granted by IBM's European headquarter in Geneva, but there was a problem finding the so-called mobile unit. In May 1946, Mr. Lykke Hansen, later to become general manager of IBM, was dispatched to Germany on a troop transport train and after several weeks he located two rather enormous trucks with what he described as "a service bureau on wheels," which had been placed at an airfield close to Bremen, and drove the lorries home. As a matter of curiosity, the installed tabulating/accumulating unit at Max Bodenhoff's Service Bureau stopped working the moment its replacement was placed in the room.

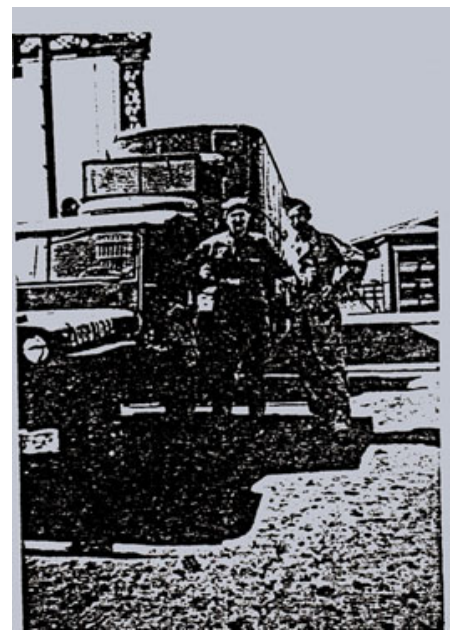

Fig. 3. One of the two lorries containing the so-called army machines brought back to Copenhagen from the U.S. Army in Germany. Parts of the machines were later installed in the City of Copenhagen's Bureau of Statistics, while the remaining parts were used at the Service Bureau [4].

Some prospective customers were lost during the first years after the war, while many others patiently waited for things to clear up. Consequently, when news of the Marshall Plan spread, customers first contracted with the Service Bureau and eventually, when restrictions were lifted, rented their own equipment. 
Some very strategic sales to the City of Copenhagen and the City of Frederiksberg marked the beginning of the large number of municipal applications that later became the foundation of first the regional Punched Card centers, later the EDP-centers that finally emerged as Kommunedata, while the central government applications led to the foundation of Datacentralen I/S in 1959. An additional user group was founded Dansk Hulkortforening - that much later in 1958, developed into Databehandlingsforeningen, now Dansk IT [9].

It is not a coincidence that the first manager of the Jutland EDP-center JKEC, Mr. Renner Andresen, was a salesman with Max Bodenhoff's Hollerith Department during the 1940s, as was Willy Olsen, Datacentralen's (Center for Danish Government Data Processing) first CEO. When IT history is told, it is important to remember the pioneers and where they were first trained and employed. This pattern of recruiting trained former IBM employees was to continue and took-off with the later introduction of the computer era; but the trend actually started in the 1940s [5].

In 1949 Max Bodenhoff's "Hollerith Department" consisted of forty-nine persons, the turnover at the Service Bureau amounted to $\$ 112,000 /$ year and the rental base, thanks to the lifting of the import restrictions, now represented a turnover of $\$ 20,000$ per month [5].

\section{Creation of IBM Denmark in 1950}

In 1947, Viggo Troels-Smith, the future first CEO of IBM DK [4], joined the Max Bodenhoff Hollerith organization; he had studied in the U.S. before the war and was hired as a salesman by IBM U.S. in 1937. During the War, he had enlisted in the Navy and participated in a punched card logistics unit. He returned back to Europe to assist in re-establishing the Nordic IBM companies and to Denmark to ensure the creation of a fully developed affiliate company. Max Bodenhoff very soon declared that he wanted to remain an independent merchant, and so the job naturally went to Troels-Smith, while T.J. Watson, who awarded a pension to Max Bodenhoff, was described by him as "more impressive than any Department Manager of a Danish Ministry" [2]. The entire Hollerith staff joined the new IBM A/S that opened its doors on 1 January 1950 in Vestre Boulevard 38 (later H.C. Andersens Boulevard).

\section{Summary - What Can We Learn from History?}

From the beginning of the automatic "punch card era," it seems that the patterns of development, operations, marketing, and competition have followed the trends repeatedly witnessed in every phase of the 'real' computer era. The driving force behind the market place was and is the intelligent combination of creative engineers and the key applications needed by advanced companies and institutions. While the characteristics for this first generation of (semi) intelligent computing were the sheer volume of the computations needed, it soon became clear that information management, cross-tabulating, and new ways of reusing large bulks of data have given rise to new business opportunities as well as cost savings. Originally focused on statistical departments in government and insurance, the toolbox of applications soon 
spread to other parts of society. In the case of Denmark, the specific challenges imposed by the German Occupation led to a pressure on creativity, particularly in the applications area, which was inherited by the newly formed IBM Denmark organization and which ensured a firm position in the market when the age of electronic computing really took off. In 1950, the tradition of efficient marketing, already introduced by Max Bodenhoff in 1920, the close partnership with customers, and the importance of employee education and training as well as educational facilities for customers were already a matter of fact.

\section{References}

1. Conolly, J.: A History of Computing in Europe. IBM, New York (1967)

2. Private correspondence of Mr. Max Bodenhoff, IBM Denmark Archives

3. Bashe, C.J., Johnson, L.R., Palmer, J.H., Pugh, E.W.: IBM's Early Computers. MIT Press, Cambridge (1986)

4. Private archives of Mrs. Elin Hansen, secretary of first CEO of IBM Denmark

5. IBM Denmark Archives

6. Powers Magazine (April 1938)

7. Before the Computers Came (Powers- Samas and more references), http: / / www . westwoodworks . net/HowItWas/BeforeComputers/index. htm

8. Science et Vie Micro Magazine. History of Bull (74) (July-August 1990), http: //www.riemarfamily.com/BullHistory/history.html

9. Heide, L.: Hulkort og EDB i Danmark 1911-1970. Systime, e-book (2005) 